\title{
Perception of Fiction for the Development of Personal Meaning at Senior Preschool Age
}

\section{Abstract}

Fiction encourages the development of a personality if children have grasped the author's idea and the value system on the level of personal meaning. The article presents a theoretical model for encouraging the development of personal meaning related to fiction at preschool age. It is based on conclusions from the areas of phenomenology, hermeneutics, social genetics, social constructivism and art pedagogy as well as studies in cognitive psychology - research in the "theories of mind" about understanding other individuals' mental states at preschool age. The structure of the model is composed of successive stages requiring an interactive introduction of a piece of fiction in a situation topical for children, with the participation of their peers and the teacher. In discussion after the perception of a piece of fiction various experiences meet, associations form, analogies in one's own experiences and those of others are discovered. The processing of the perceived data continues in productive children's activities and they become personified in narrative interconnections: in children's stories about a piece of fiction.

The aim of the study is to create a theoretic model for the development of personal meaning in the perception of a fairy tale and prove its productivity by revealing the manifestation of the criteria related to personal meaning in children's stories determining their levels. The study described in the article has been carried out in two stages: the aim of Stage 1 is to create a model for the development of personal meanings in perceiving fairy tales; the aim of Stage 2 is to investigate the productivity of the model for the development of personal meanings and work out criteria for the manifestation of personal meanings in children's stories generalizing them in levels of personal meaning development.

Materials and methods include content analysis of stories narrated by children aged 5-6. After analysing the acquired data it is possible to single out several criteria and indicators for the manifestation of personal meaning as well as the levels of personal meaning in perceiving fairy tales. When summarizing the results, it can be concluded that the involvement of a fairy tale into a context topical for children, its interactive perception and social interaction with peers and an adult in a discussion, as well as the portrayal of the perceived information in a productive activity, encourages the development of personal meaning. This proves that fiction may encourage selfregulation of senior preschool children in their relationships with peers that are based on the intentions, experience and understanding of the situation as well as empathy of the other peers. 
Key words: personal meaning, social interaction, interactive perception of a fairy tale, meaningful verbal units, transformation of experience, depth offairy tale perception, content analysis of children's stories

\section{Introduction}

The study focuses on the development of personal meaning for preschool age children concerning the author's idea included in a piece of fiction, world outlook and values. Interest in this topic has been aroused by several factors. Firstly, theoretical literature pays considerable attention to fiction and folklore and their functions (educational, learning, aesthetic, pleasure or compensatory) that influence the development of a personality. Fiction and folklore portray spiritual culture coded in artistic language and implement children's communication with it. Communication not only gives information, not only records sensual perceptions in lexically semantic units, but with the help of means of expression and images characteristic of it, various behaviour and action models, gives birth to emotions; it touches upon the world of feelings, allows to grasp the idea of a piece of fiction more deeply, in such a way enriching and transforming personal meanings about objects of reality, events and phenomena depicted in the text. Secondly, the modern world is known for its value fluctuations, mass culture, information variety and sometimes its contradictions that interfere with general human values and the development of personal meanings. Since the beginnings of its development in the middle of the 19th century, the issue about values has always been topical in Latvian children's literature. General human values allow children to see, hear, feel and understand the world and themselves as somebody belonging to the world and finding their place in it. Various genres in children's literature portray home and family, work and duty, nature and life, wisdom and joy of learning as a value simultaneously fostering imagination (Stikāne, 2005). With the help of the artistic value of the word, it can ignite the experience of the "beautiful" and the "good", the development of feeling synthony (Liegeniece, 2004). Thirdly, studies about the perception of the fiction morals at preschool age show that modern children of preschool age have vague and situational ethical notions (Lieǵeniece, 2004; Смирнова, Медведева, 2004). The study by Liegeniece proves that not always do children perceive the morals hidden in fairy tales. About half of the children aged 5-6 who participated in the study do not perceive it. Only $10-26.6 \%$ of all children are ready to empathize with the one who suffers. The perception of the morals hidden in fairy tales is hindered by several factors. One of them is interpretation of a fairy tale on the level of personal meaning in relation to one's own life experience and perceptual peculiarities. There are children who judge the situation portrayed in a piece of fiction logically and rationally from the point of "useful - useless", however, they do not understand "the evil" and "the good". The understanding of "the beautiful", too, as a criterion for values impedes children's ability to understand the relations 
between "the good" and "the bad". There are children who identify themselves with characters that ignore general human values. Children occasionally demonstrate power, strength and selfishness and get carried away with the behaviour of such characters. Therefore an additional factor impeding the perception of the morals in fairy tales can be singled out: it is disrespect for children's own personal meaning. That does not encourage communicative interaction between adults and children - it is merely the subject's influence on the object which in turn causes the following problem: the fairy tale as a method for moral upbringing does not implement its potentials for developing feeling synthonies and empathy incorporated in the tale (Lieǵeniece, 2004, 115-118). In everyday situations children are directly involved in events and relations with their peers; they experience various emotions and act spontaneously. It is hard for them to regulate their response, actions and behaviour and to assess them critically. When listening to a piece of fiction, children are placed in a situation that simultaneously combine their identification with characters, the sense of presence in the events and a risk-free feeling of safety that could allow children to cast an impartial look at the actions and behaviour of the characters and events, analyse them and generalise conclusions. However, the results of the study by Liegeniece mentioned above show that when there is no common intention of the teacher and the child towards a piece of fiction, children remain within the realm of their previous personal meaning, and neither enrichment, nor transformation takes place. This encourages seeking for an approach for implementing a dialogue between children and the piece of fiction, accentuating the role of the teacher and strategies used.

Phenomenology draws attention to the intention of the subject's consciousness and intersubjectivity in perceiving the outside world, processing its information into a subjective meaning (Huserls, 2002; Mamardašvili, 1994). As the Georgian phenomenologist Mamardašvili states, in order that the thinking process can start, it is important to select something to think about - to become aware or to mark the field for thoughts (Mamardašvili, 1994). Thus, the subject's attention must be drawn to the object, phenomenon or event. Mamardašvili calls it a state to be experienced that every person goes through. It is some kind of a situation, an aggregate of conditions, a proceeding of an event. Consciousness intention and ability to synthesize fix a thing in the objective reality, and it penetrates the inner scheme of consciousness. In phenomenology, consciousness or transcendental ego is characterised as a flow in time in which not all perceptions during the moment of perceiving are conscious or understood. However, after some time in a specific situation or conditions they can actualise themselves and unite with the perception of the moment thus constituting its meaning. Mamardašvili comments that when "an event has happened between me and this object which has wrapped in this object the meaning of my past that has not become present at that moment, that has not emerged on the analytical surface...", but at the moment of current perception previous experience produces itself and the object becomes 
a phenomenon (Mamardašvili, 1994, 75). The above conclusions allow suggesting that context encourages the acquisition of the content of a piece of fiction offered to a child: a topical situation and experience synthesise with the new information, and as a result meaning emerges. Inter-subjectivity is another important factor for the acquisition of meaning. Taking into consideration that inter-subjective experience is always broader than individual experience, not only interaction with literature in the aspect "a child - literature" is important at preschool age, but also social interaction between "a child - a child" and "a child - an adult". Within social interaction interrelation of subjective meanings takes place, and every child's personal meaning has a possibility to broaden and transform.

Sociogenetic approach (Lawrence and Walsiner, 2003) and social constructivism (Bednar, et al, 1992), too, see the interiorisation of culture in a social interaction where subjects construct their own personal meanings on the basis of interpretation of personal experience. The latest studies of cognitive science are significant in the "mind theory" aspect: they focus on studying children's understanding of people's mental conditions. Bruner (Bruner, 1996) points to the assessment of children's egocentric perspective mentioned by Piaget. He believes that "egocentrism as such is not a problem" (ibid, 92). It manifests only when children do not succeed in perceiving a situation, the structure of an event as their experience is yet too limited. Within the context of the "theory of mind", Harris (Harris, 1992) offers a theory of simulation, that is, children of preschool age can grasp psychic states of other people by taking or simulating various roles. These kinds of simulations develop gradually, and children's experience has an invaluable significance in this process of inquiry. Flavell believes that a variety of experience creates the basis for concept developing about the spiritual world of a human being and understanding of other people's behaviour (Flavell, 2000, 23). It can be concluded that the situation experience, circumstances or context and social interaction are mentioned in scientific literature as significant factors for the generation of personal meaning. Conclusions from hermeneutics about the reflection of information and interpretation cast a wider look on social interaction in a discussion after listening to a piece of fiction. Heidegger (Heidegger, 1996) sees interpretation as a technique to explain the existing state of understanding, i. e. an already existing experience of some kind. It may be acquired spontaneously and has not been completely expanded and recognised, yet it exists within experience. While interpreting, whatever is known is identified first, then compared to the new information and a decision about the relationship between the new and the known is taken (Мартин, Рингхэм 2009). Discussion, in its turn, encourages openness to the experience of others, whereas the linguistic expression reveals meaning. Gadamers' (Gadamers, 2002) conclusions about art as a game are also noteworthy. He distinguishes several essential processes in the "art game" with a recipient: the recipient's co-playing with a piece of art in which a room for creating variations of the piece of art is made, and that has to be filled with one's own forms of variations. Gadamers points out that a 
piece of fiction is always a product of reflection, and it requires a game of reflection to be discovered. A form must be seen and actively produced about the topic the story covers. In order that can happen, many things must be connected; the text must be "decoded" on the basis of images created by words (Gadamers, 2002, 65-66). At preschool age, researchers suggest using dialogical alias interactive reading for decoding the text into images; that is, while reading and in a discussion afterwards, an adult helps children to find out the meaning of the words, forms associations about things that exist in their experience without turning the process of perception into a discussion so that children would be able to perceive the text in a meaningful entirety (Doyle and Bramwell, 2006, 555-557). Gadamers, too, draws attention to the communication between the recipients with the help of a piece of art that unites everyone and prevents fragmenting due to separate experiences and separate conversations while discussing art (Gadamers, 2002, 82). When looking for a teaching approach that would encourage the development of personal meaning of a piece of fiction, we took into account Gadamers' conclusions about the stages of the perception of a piece of fiction reflecting how initial interest about a piece of fiction in the pre-communicative stage turns into emotional experience in the communicative stage, then into emotional generalisation and comprehension in the post-communicative stage (Раппопорт, 1978).

\section{Aim of the study}

The aim of the study is to summarise theoretical conclusions. We extracted the most significant factors on which the implementation of the aim of the 1st stage of the study is based: the elaboration of a theoretical model of the development of personal meaning:

- A situation topical for a child, circumstances as a context in which a piece of fiction is offered (relationships between children in a group, events in the outside world, etc.). A piece of fiction selected in correspondence with the situation ensures evoking of children's interest and actualizing of their experience.

- The link between experience and the plot of a piece of fiction, its actualising and reconstruction encourage the decoding and interpretation of a fiction text in a discussion. Explanation of words and visual materials, too, help in decoding a text successfully. That, in its turn, gives rise to co-experiencing, implements co-playing and co-creating along with events described in a piece of fiction.

- A discussion and strategic questions by the teacher after the perception of a piece of fiction encourage the process of entering into the spirit of the character's experiences, understanding of their perspectives, revelation of analogies in one's own and other people's experiences as well as voicing of opinions.

- Children's productive activity (constructive, artistic actions, etc.) after a 
discussion encourage a repeated reflection on the issues raised in the piece of fiction and their comprehension.

The structure of the theoretical model is shown in Figure 1:

Figure 1. Theoretical model for the development of personal meaning in perception of fiction

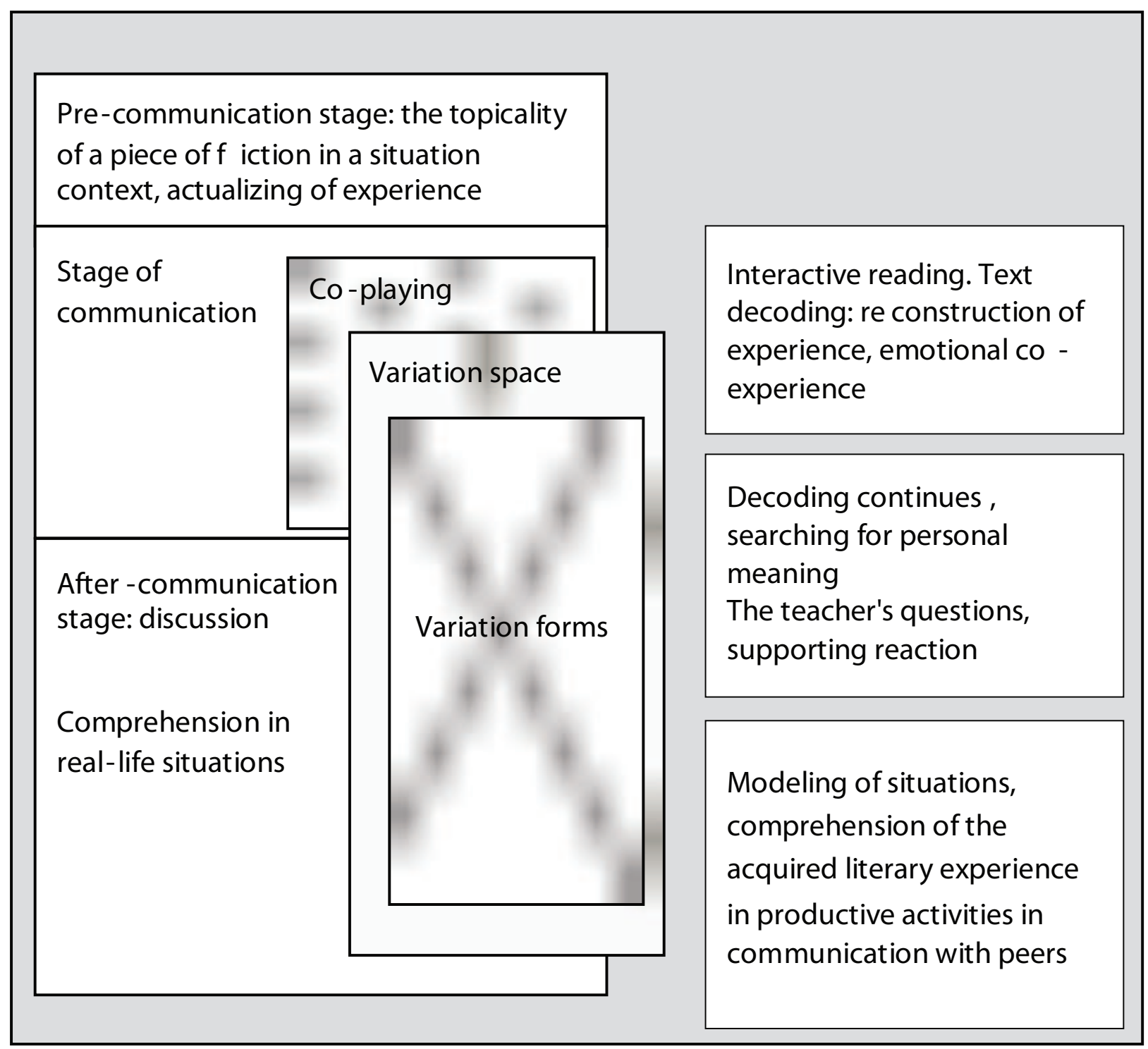

The aim of the $\mathbf{2 n d}$ stage of the study is to examine the productivity of the model for the development of personal meaning and to elaborate the criteria for the manifestation of personal meaning in children's stories, generalizing them in levels of personal meaning development.

The following enabling objectives have been set to achieve the aim:

1) to find out the depth of perception of a fairy tale (comprehension of the nucleus of ideas, turning points, actions and feelings of characters);

2) to discover the expression (signs) of personal meaning in semantic units of 
children's language;

3) to establish criteria and levels of personal meaning in the perception of a fairy tale.

\section{Materials and methods}

Two groups of children aged 5-6 from preschool educational institutions participated in the research: a control group and an experimental group with 11 children in each. As a piece of fiction Purviṇa's fairy tale "Lācēna ziema" ("A Bear Cub's Winter") was chosen. There are no explicit binary oppositions in the fairy tale: it portrays a situation children experience on daily basis when they are in a group of peers with various opinions and interpersonal conflicts. It is based on children's egocentric view of the situation that has emerged. The children's behaviour and actions are derived from their desires, objectives and feelings related to them. When involved into a conflict and experiencing strong emotions, children have difficulties noticing the perspective and feelings of other children.

To acquire the research data - children's stories about the fairy tale - the narrative approach was used. To process the data, the hermeneutical approach and the strategy of analytical induction were applied: the content analysis of children's narratives and the generalisation of their results in relation to the criteria and levels of personal meaning development. The data acquired were analysed in several steps (Ricoeur, 1976; Kroplijs, Raščevska, 2004; Nygren and Blom, 2001):

1) getting acquainted with the stories of all children in general, coding of the stories and analysing the depth of the perception of the fairy tale's idea;

2) a structural analysis (explanation) of each narrative and coding of the semantic units with an objective to uncover meaningful units that act as signs of a developed personal meaning in the children's language and allow to elaborate criteria and indicators for personal meaning;

3) general interpretation and assessment of all the results of the text analysis according to the aim of the study - elaboration of criteria and levels of personal meaning development.

\section{The study process}

The control group was offered to listen to the fairy tale without using the worked-out model, i.e. without linking the plot to a situational context of specific relationships in the group, without using dialogical reading elements and a discussion after reading. After listening to the fairy tale, children were invited to share their viewpoints on the events, the characters' behaviour and actions in the fairy tale (what the story is about, what happens in it, why).

In the experimental group the process of getting acquainted with the fairy tale was going on within the context of the elaborated model. The particular fairy-tale was selected because of a conflict between two girls: one of them unintentionally had broken a new and attractive toy the other had brought from home. The conflict 
grew bitter and serious as each of the girls saw only her own perspective. One of them tried to talk the other children into stopping being friends with the "guilty one".

\section{Results of the Study}

1. Perception of the fairy tale as an entirety.

First of all, it is important to find out how the fairy tale has been perceived in its entirety as it defines the development of personal meaning and its level. The analysis of the narrative is based on the theory of interpretation by Ricoeur (Ricoeur, 1976): interpretation as the dialectic between explanations and comprehension. It requires an initial introduction to the text in its entirety, then an analysis of its structure (explanation) with an aim to discover meaningful units and to gain a higher level of understanding as a result. After obtaining the children's stories from both groups, we divided them into several sections, each story being assigned a special code.

The results of the control group: 9 out of 11 stories are very short, they are based on the assessment of a character's action: "I liked when...," "I did not like when..." without going deeper into the causes of behaviour or motivation for the action. When asked such questions as "Why did you like it?" or "Why didn't you like it?", children respond:"Because of a gift","Because they laughed", linking the assessment of the characters' behaviour to its outward expression only, instead of "providing some inner motivation". We coded this type of stories under the name "assessment stories". The remaining two stories are very short and superficial. Children name actions performed by the characters without entering into the causes of events, the motivation of characters' behaviour, without having an attitude towards their actions or feelings. The event is mainly characterised with the help of verbs, for instance, "laughed...", "took offence and went home...," "bought a ball...". We coded this type of stories under "stories naming actions".

The stories in the experimental group are much more multiform. There are two "assessment stories" in the experimental group and one "story naming actions". In addition, we distinguished two more types of stories that were not present in the control group. According to their plot, they can be coded under the following names: "emotionally assessing stories" and "interpretative stories". "Emotionally assessing stories" differ from "interpretative stories" by a reproduction of a fairy tale with an emotional assessment of characters' actions and attitudes using an expressive voice and one's own verbal units that have not been used in the fairy tale. For instance, "the hare was a very, very good friend"; "...they were very good friends and they loved each other.... We gave this code to three stories. In "interpretative stories" children not only assess characters' actions but reveal understanding of what has happened including explanations in the story, in our case:"...they laughed a bit because it was funny that snowflakes should twitter..."; "...they laughed because they were only joking..."; "the hare was not at all sorry for his money... maybe he 
already has a sledge... but if not, then not. When he saves enough money again, he will buy it. It is better to have a friend than a sledge... you can talk to a friend... play various games...; "...took all the money... and thought that it is better that the bear is not sad than to have a sledge. He went to a shop and saw a toy - a ball with winter inside, and grew happy; now the bear will see winter and will be happy. And that is what happened... and they both were the happiest best friends ever...." There are five "interpretative stories". Through interpretations children's quest for personal meaning emerges - it is confirmed both to themselves and others. The quantity of the story types in the control and experimental group is presented in Table 1:

Table 1. Types of stories in the control and experimental group

\begin{tabular}{|l|c|c|c|c|}
\hline $\begin{array}{c}\text { Types and number of } \\
\text { stories }\end{array}$ & $\begin{array}{c}\text { "Story naming } \\
\text { actions" }\end{array}$ & $\begin{array}{c}\text { "Assessing } \\
\text { story" }\end{array}$ & $\begin{array}{c}\text { "Emotionally } \\
\text { assessing story" }\end{array}$ & $\begin{array}{c}\text { "Interpretative } \\
\text { story" }\end{array}$ \\
\hline Control group & 2 & 9 & - & - \\
\hline Experimental group & 1 & 2 & 3 & 5 \\
\hline
\end{tabular}

Differences between the stories in the control and experimental group explain the level of perception of the story plot. In order to analyse it, the fairy tale was divided into semantic fragments with a new central event, a turning point that gives an impulse and motivation for the characters' further actions and the development of the events. We analysed the comprehension and portrayal of the above semantic fragments in every child's narrative (see Figure 2)

Figure 2. Most significant semantic fragments of the fairy tale

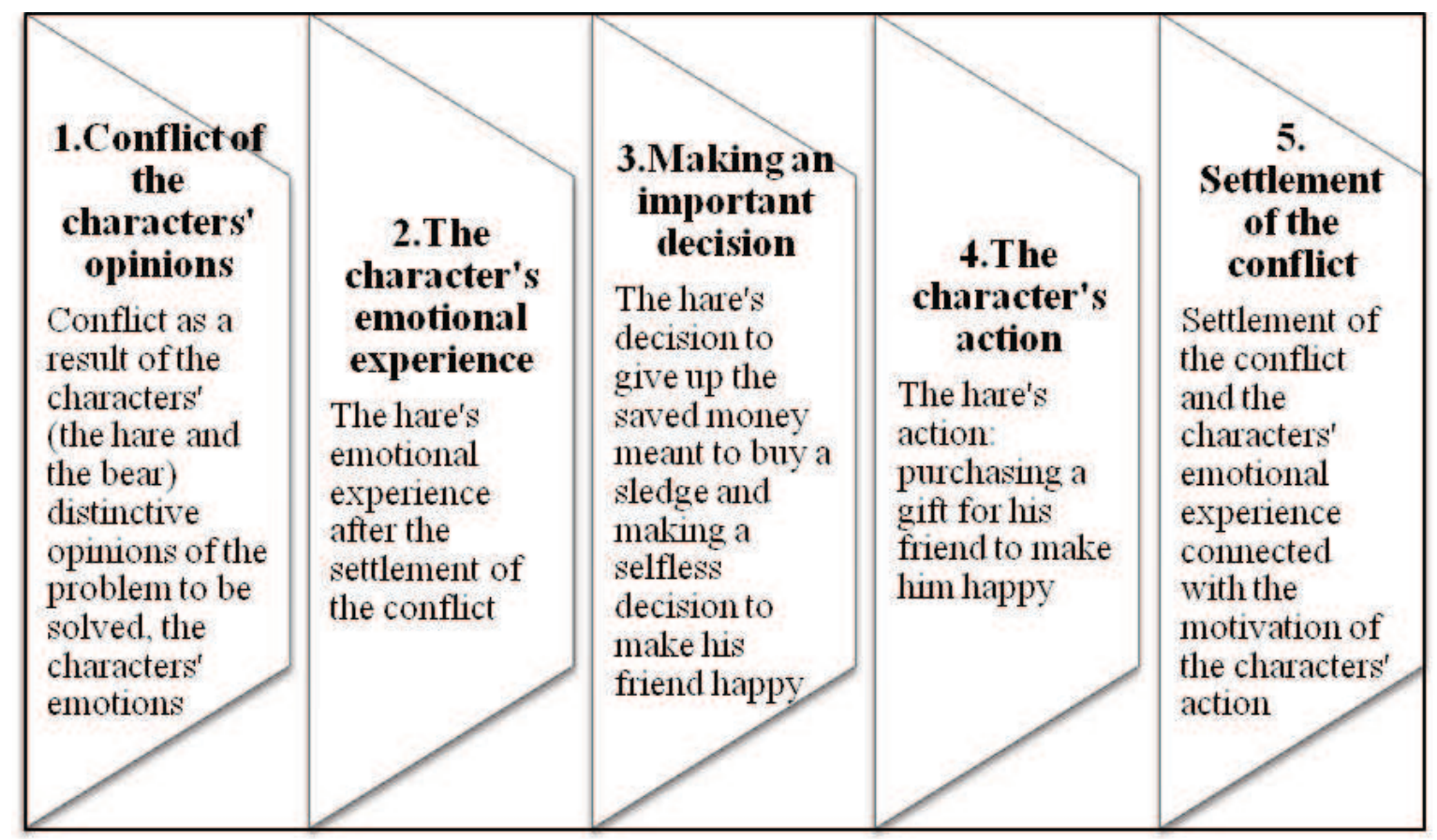


The analysis of the stories in the control group revealed that only one out of eleven children had recorded the first four semantic fragments of the fairy tale. Moreover, fragments 2 and 3 were mentioned superficially without going into the depth of the causes and consequences of the events and character actions. The rest of the children depicted only several fragments in their stories that seemed important to them and were linked to their experience, to their existing personal meaning: eight children in their stories depicted fragments 1, 4 and 5 showing the origination of the conflict and its solution: the "guilty" hare bought a gift which is why the bear was happy. When telling about the origination of the conflict, four children had perceived the feelings of only one character (the bear) and his perspective without paying attention to the feelings of the other character (the hare) and the motivation for his decision - to buy a gift for the friend to make him happy. It shows that for children their own personality matters most of all - it is painful when you are laughed at. The one who laughs is bad; the motivation of the behaviour is not analysed - it is accepted as a negative fact. All eight children accentuated the purchased gift (fragment 4) in their stories - the hare's obvious action without analysing his true motives (to make the friend happy) as well as the solution of the conflict saying that the bear was happy because he had received a gift - a new toy (in the fairy tale the bear is happy as he has the best friend in the world who wants to make him happy). Emphasis was laid on presenting the gift as a positive action that reveals the expression of children's personal meaning - "a gift is something very good".

The fact that ten children did not portray important semantic fragments of the tale, instead perceiving only the external aspects of the conflict and its solution, indicates that children had not acquired personal meaning about the morals of the fairy tale. The causes of the conflict, the emotional experience of both characters, the hare's dilemma - to buy a sledge for himself for the money he has saved or a snow ball for the friend in order to make him happy, the ability to give up something pleasant for the sake of a friend had remained unclear.

In the experimental group all semantic fragments of the fairy tale were depicted by three children, however, in contrast to the children in the control group, they revealed the meaning of each fragment in an emotional and interpretative way. The stories of the remaining eight children tell about the solution of the conflict. The hare's feelings after the argument (fragment 2) were mentioned by three children. The hare's decision to buy a gift (fragment 3 ) was mentioned by seven children assessing the hare as good since he did not grudge his money for his friend's gift. The hare's action - the purchasing of the gift - was mentioned by eight children, whereas the resolution of the conflict as something very positive and successful for the hare and bear's further friendship was mentioned by all children. The perception of the semantic fragments in the control and experimental group is compared in Table 2: 


\begin{tabular}{|l|l|l|l|c|c|}
\hline $\begin{array}{l}\text { The semantic } \\
\text { fragments of the } \\
\text { fairy tale and } \\
\text { the number of } \\
\text { children who } \\
\text { perceived them }\end{array}$ & $\begin{array}{l}\text { 1. Clash } \\
\text { between } \\
\text { the } \\
\text { viewpoints } \\
\text { of } \\
\text { characters }\end{array}$ & $\begin{array}{l}\text { 2. Emotional } \\
\text { experiences } \\
\text { of characters' } \\
\text { search for } \\
\text { conflict } \\
\text { resolution }\end{array}$ & $\begin{array}{l}\text { 3. Decision } \\
\text { making. }\end{array}$ & $\begin{array}{l}\text { 4. Outward } \\
\text { action of } \\
\text { characters }\end{array}$ & 5. Conflict \\
resolution
\end{tabular}

It has to be noted that it is not the numerical difference that is the most important, i.e. how many children in each group perceived every semantic fragment; it is the depth of their comprehension. Stories about the fairy tale by the children in the experimental group are of a general character in contrast to those of the children in the control group. The children did not attempt relating the fairy tale in detail - they related and interpreted it simultaneously as based on their understanding, i. e. on their personal meaning. That is the reason why semantic fragments were not mentioned separately. The children's perception was revealed through their interpretation and judgements that were present only in a few stories by the children in the control group. The analysis allows to conclude that a difference can be observed in the perception of the fairy tale as an entirety as well as the depth of the idea, which shows the levels of personal meaning. The fact that there is not a single interpretative story in the control group confirms theoretical conclusions that interpretation follows recognition and identification (Мартин, Рингхэм, 2009). To interpret an object, it has already to have been involved in the person's experience. Interpretation is an ability to conceptualise what has been given before, it encourages comprehension of meaning (Heidegger, 1996). Mamardašvili speaks about comprehension as a process of tying up many separate threads (Mamardašvili, 1994, 43)."Many separate threads" do not rise to the surface or become topical after a fairy tale has been heard once without talking it over. Children perceive a piece of fiction on the level of the existing meaning, and no transformation takes place. A discussion encourages openness to other opinions, it actualises experience and fosters thinking.

Based on the acquired results, the levels of perception of the idea in a piece of fiction may be established along with their manifestation in children's stories: 
1. Perception of separate semantic fragments and the naming of the characters' actions and feelings, as well as behaviour; actions assessment is not rendered.

2. Perception of several interconnected semantic fragments related to the identification in personal experience; assessment of the characters' behaviour and actions that are linked to their external significance and manifestation.

3. Emotional perception of several interconnected semantic fragments. A typical way to retell a story and give emotional assessment of its events, actions and the characters' behaviour using one's own verbal means of expression;

4. Perception of a piece of fiction in its entirety, interpretation involving an assessment of what has happened, explanations and one's own judgements.

To uncover the above levels from the point of view of their content, we focused on the structural analysis of each child's story. It helped to single out meaningful verbal units proving to be signs of developed personal meaning in the children's language, as well as to elaborate indicators and criteria for personal meaning.

2. Results of the structural analysis of the stories and their interpretation

While analysing each story, we looked for signs of personal meaning (semantic verbal units and emotional expressions) in the children's stories and then coded them. A coding system was established which we generalised in the form of criteria and indicators of the personal meaning of the fairy tale (see Table 3).

\section{Table 3. Criteria and indicators of children's personal meaning about the fairy tale}

\begin{tabular}{|l|l|l|}
\hline \multicolumn{1}{|c|}{ Criteria } & Indicators & \multicolumn{1}{c|}{ Desription of indicators } \\
\hline $\begin{array}{l}\text { Criterion 1 } \\
\text { Understanding } \\
\text { of the } \\
\text { emotional } \\
\text { experiences of } \\
\text { the characters }\end{array}$ & Low & $\begin{array}{l}\text { 1.1. The characters' emotional experiences are not } \\
\text { mentioned; the characters' emotional experience are named } \\
\text { but no causes are given. }\end{array}$ \\
$\begin{array}{l}\text { 1.2. The characters' emotional experiences are linked with } \\
\text { their actions and behaviour; } \\
\text { 1.3. The characters' emotional experiences are linked with } \\
\text { the inner motivation of their actions and behaviour; they are } \\
\text { seen interconnectedly with events and their causes. }\end{array}$ \\
\hline
\end{tabular}




\begin{tabular}{|l|l|l|}
\hline $\begin{array}{l}\text { Criterion 2 } \\
\text { Understanding } \\
\text { of the actions } \\
\text { and behaviour } \\
\text { of the } \\
\text { characters }\end{array}$ & Low & $\begin{array}{l}\text { 2.1. Enlisting of the characters' actions and behaviour } \\
\text { without giving reasons; mainly nouns and verbs are used } \\
\text { ("the hare laughed", "the bear went", etc.); } \\
\text { 2.2. The characters' actions and behaviour are associated } \\
\text { with the event; the inner motivation of the actions and } \\
\text { behaviour are not understood. } \\
\text { 2.3. The characters' actions and behaviour are understood } \\
\text { interconnectedly with the essence of the events and their } \\
\text { causes ("bought a gift to make happy"); sometimes the } \\
\text { narrative is given in the 1st person, involving situations } \\
\text { that have not been mentioned in the fairy tale. It shows } \\
\text { comprehension and manifestation of one's own meaning. }\end{array}$ \\
\hline $\begin{array}{l}\text { Criterion 3 } \\
\text { Assessment of } \\
\text { the actions and } \\
\text { behaviour of } \\
\text { the fairy tale } \\
\text { characters }\end{array}$ & Low & $\begin{array}{l}\text { 3.1. No assessment or impersonal, indifferent assessment is } \\
\text { given; it enlists adjectives (good, bad) without expressing } \\
\text { emotions and personal attitude. } \\
\text { 3.2. Emotional assessment is given using one's own verbal } \\
\text { units (adverbs, adjectives). } \\
\text { 3.3. Interpretative assessment with one's own attitude is } \\
\text { given. }\end{array}$ \\
\hline
\end{tabular}

It is possible to uncover several levels of personal meaning in perceiving fairy tales after taking into account the depth of comprehension of the tale's idea and the indicators of personal meaning. The levels of personal meaning and the respective number of children from the control and experimental groups are shown in Table 4:

Table 4. Levels of personal meaning in perceiving the fairy tale

\begin{tabular}{|l|l|c|c|}
\hline \multicolumn{1}{|c|}{ Level } & \multicolumn{1}{|c|}{ Description of the level } & $\begin{array}{c}\text { No of } \\
\text { children in } \\
\text { the control } \\
\text { group }\end{array}$ & $\begin{array}{c}\text { No of children } \\
\text { in the } \\
\text { experimental } \\
\text { group }\end{array}$ \\
\hline $\begin{array}{l}\text { Level 1 } \\
\text { (very } \\
\text { low) }\end{array}$ & $\begin{array}{l}\text { Perception of separate semantic fragments and } \\
\text { the naming of the characters' actions ("went", } \\
\text { "laughed", "looked", etc.) without stating the } \\
\text { characters' motivation and feelings, or assessing } \\
\text { their behaviour and actions. }\end{array}$ & 2 & 1 \\
\hline
\end{tabular}




\begin{tabular}{|c|c|c|c|}
\hline $\begin{array}{l}\text { Level } 2 \\
\text { (low) }\end{array}$ & $\begin{array}{l}\text { No explicit emotional expressions in relation } \\
\text { to the plot of the story. Perception of several } \\
\text { interconnected semantic fragments of the fairy } \\
\text { tale based on the identification of the notions } \\
\text { already existing in the children's experience. } \\
\text { Neutral assessment of the characters' actions } \\
\text { and behaviour ("good", "bad"). The characters' } \\
\text { emotional experience is revealed without } \\
\text { causes or motivation provided. The narrative is } \\
\text { short. }\end{array}$ & 9 & 2 \\
\hline $\begin{array}{l}\text { Level } 3 \\
\text { (average) }\end{array}$ & $\begin{array}{l}\text { Perception of several interconnected semantic } \\
\text { fairy tale fragments. Emotional openness to } \\
\text { the piece of fiction manifests through one's } \\
\text { own verbal means of expression, emotional } \\
\text { language and voice. Both characters'feelings are } \\
\text { accepted. The characters'emotional experiences } \\
\text { are linked with their outward actions, not with } \\
\text { the motivation of their behaviour. The narrative } \\
\text { reminds a retold story. }\end{array}$ & - & 3 \\
\hline $\begin{array}{l}\text { Level } 4 \\
\text { (high) }\end{array}$ & $\begin{array}{l}\text { Perception of the fairy tale as an entirety. } \\
\text { Emotional attitude is manifested as interest } \\
\text { and willingness to explain situations and } \\
\text { both characters' emotional experiences and } \\
\text { behaviour. The storyline is not directly related } \\
\text { but interpreted freely - the characters' feelings, } \\
\text { their actions and behaviour are explained and } \\
\text { justified; sometimes the narrative is in the 1st } \\
\text { person. The characters' emotional experience is } \\
\text { linked with the inner motivation of their actions } \\
\text { and behaviour; they are seen interconnectedly } \\
\text { with the events and their true causes. One's own } \\
\text { ideas are incorporated in a creative manner. }\end{array}$ & - & 5 \\
\hline
\end{tabular}

It must be noted that during the discussion (in the experimental group) the teacher paid attention to the feelings of both girls involved in the conflict allowing them to voice their opinions unrestrictedly. The children were encouraged to recall situations in which they had hurt someone without intention or were hurt themselves. Disregarding the great disappointment and anger of the broken toy's owner, the girl listened with confusion to the other girl telling how scared she had felt when the toy broke and how sorry she was. Later on, in the course of the day, both girls looked for a way to mend the toy with the help of the teacher.

The analysis of the acquired data allows to draw the following conclusions:

1. When a fairy tale is involved in a situation where children have interrelations, emotions are brought about; the morals of the fairy tale is better perceived 
if it is linked to significant and recognisable experience.

2. Interactive perception of a fairy tale and a discussion encourage synthesis of prior experiences and new information enriching and transforming children's personal meaning both in regard to events taking place in the story as well as adequate events in real relationships. This is shown by a comparison of a story analysis given by the children in the control and experimental groups. Common intention of the teacher and children towards a piece of fiction forms subject - subject relationships in which the experience and opinion of each member of the discussion is valuable; the freedom in manifesting it fosters children's initiative, independence in judgements and acquisition of personal meaning.

3. The portrayal of the perceived information in an artistic activity allows children to re-interpret the plot of a fairy tale and comprehend it. This is reflected by the type of narration: emotions have acquired a generalized character; children explain and pass their judgement about the events described.

4. Each child individually develops his/her own personal meaning of a fairy tale. This is revealed by levels of the development of personal meaning. Every child's life and literary experience differs, and so does the ability to perceive and process information, as well as the child's individual openness to a discussion.

5. The study allows to assume that fiction may encourage self-regulation of senior preschool children in relationships with their peers that are based on the intentions, experience and understanding of the situation as well as other peers' empathy. This can become true if children are involved in interactive problem solving and voicing their opinions. It is evidenced by the ability of the children involved in a conflict to suppress their feelings, by their desire to search for a solution of the problem together with the teacher as well as by the use of the 1st person in telling the events of the story. Children do not imitate literary characters' actions and behaviour directly - they undertake their roles and identify with them. This is a significant step in the development of selfregulation as they have an opportunity to imagine themselves as characters which are and at the same time are not them.

\section{References}

1. Bednar, A. K., Cunningham, D., Duffy, T. M. \& Perry, J. D. (1992). Theory into Practice: How do we think? In: Duffy, T. M. \& Jonassen, D. H. (Eds.) Constructivism and the Technology of Instruction: A Conversation. Hillsdale, NJ: Lawrence Erlbaum, p. 17-34. 
2. Bruner, J. (1996). The Culture of Education. Harvard University Press, p. 224.

3. Doyle, B. G, Bramwell, W. (2006). Promoting Emergent Literacy and Social-emotional Learning through Dialogic Reading. International Reading Association, DOI: 10.1598/ Rt.59.56, p. 554-564.

4. Flavel, J. H. (2000). Development of Children's Knowledge about the Mental World. International Journal of Behavioral Development, Vol. 24 (1), p. 15-23.

5. Gadamers, H. G. (1999). Patiesiba un metode [The Truth and Method]. Rĩga: Jumava, 508 lpp. (in Latvian).

6. Gadamers, H. G. (2002). Skaistā aktualitāte. Māksla kā spēle, simbols un svētki [The Beautiful Reality. Art as Play, Symbol and Celebration]. Rīga: Zvaigzne ABC, 128 lpp. (in Latvian).

7. Harris, P. L. (1992). From Simulation to Folk Psychology: The Case for Development. Mind and Language, Vol. 7, p. 120-144.

8. Heidegger, M. (1996). Being and Time. Albany: State University of New York Press, p. 487.

9. Huserls, E. (2002). Fenomenologiija [Phenomenology]. Rīga: FSI, 438 Ipp. (in Latvian).

10. Kroplijs, A., Raščevska, M. (2004). Kvalitatīvās pētniecibas metodes sociālajās zinātnēs [Qualitative Research Methods in Social Sciences]. Rīga: RaKa, 176 Ipp. (in Latvian).

11. Lawrence, J. A. \& Jaan Valsiner, J. (2003). Making Personal Sense: An Account of Basic Internalization and Externalization Processes, Theory \&Psychology, Vol. 13, p. 724-752.

12. Lieǵeniece, D. (2004). Bērna un pedagoga "vienpriekšmeta darbïba" pasaku uztverē [Child and Teacher's "Uni-object" Activity in Fairy Tale Perception]. Starptautiskās zinātniskās konferences Teorija un prakse skolotāju izglïībā // rakstu krājums. Rīga: RPIVA, 115.-118. Ipp. (in Latvian).

13. Mamardašvili, M. (1994). Domātprieks [Joy of Thinking]. Rīga: Spektrs, 201 Ipp. (in Latvian).

14. Nygren, L., Blom, B. (2001). Analysis of Short Reflective Narratives: a Method for the Study of Knowledge in Social Workers' Action. Qualitative Research, Vol. 1, p. 369384.

15. Ricoeur, P. (1976). Interpretation Theory: Discourse and the Surplus of Meaning. Fort Worth: Texas Christian University Press.

16. Stikāne, I. (2005). Vērtïbu pasaule latviešs bērnu literatūrā [World of Values in Latvian Children's Literature]. Rīga: RaKa, 191 lpp. (in Latvian).

17. Мартин, Б., Рингхэм, Ф. (2009). Словарь семиотики [Dictionary of Semiotics]. Москва: УРCC, c. 254 (in Russian).

18. Раппопорт, С. (1978). Om художника кзрителю [From Artist to Audience]. Москва: Советский художник, с. 224-225. (in Russian)

19. Смирнова, Е., Медведева, Е. (2004). Любимые герои современныхдошкольников [Favourite Heroes of Modern Pre-school Children]. В: Толерантность в подростковой и молодежной среде, под ред. В. С. Собкина. Москва: ЦСО, с. 10 48 (in Russian). 
Professor Dr. habil. paed. Daina Lieǵeniece

Liepāja University

Address: Baseina iela 9, Liepāja, LV-3401, Latvija

Phone: (+371) 29937748

E-mail: pedagogija@liepu.Iv

Lecturer, Mg. paed., doctoral student at the Liepāja University Inese Freiberga

Riga Teacher Training and Educational Management Academy

Address: Imanta 7. līnija 1, Rĩga, LV-1083, Latvija

Phone: (+371) 29169285

E-mail: inese.freiberga@rpiva.Iv 